\title{
FAMILY ROLE IN SHAPING CHARACTER ISLAM IN EARLY CHILDHOOD THROUGH HABITUATION METHOD
}

\author{
Khambali \\ Program Studi Pendidikan Agama Islam, Fakultas Tarbiyah dan Keguruan \\ Universitas Islam Bandung \\ Jl. Ranggagading No. 8, 40116, Bandung, Indonesia \\ Email: ust.hambali@gmail.com \\ DOI: $10.29313 /$ tjpi.v6i1.2382 \\ Accepted: April 19th, 2017. Approved: July 20th, 2017. Published: July 20th, 2017
}

\begin{abstract}
One of the indicators of success in educating children of Muslim families is if the characters are owned by the child, especially early childhood by the values of Islam. An educational method to be applied is habituation. The results of this research were 1) the factors that influence the formation of character early childhood can be categorized into four ways, namely: (a) the first educational environment, the family is represented by parents, (b) family life seen from various aspects, socioeconomic status, as well as family life philosophy, (c) family upbringing, and (d) the activities based on common religious parents by involving early childhood; and 2) habituation is done early childhood with parents can be categorized into 2, namely: (a) habituation greeting, such as greetings, and others; and (b) habituation is shown in deeds, such as: leaving the flurry of activity when he heard the call to prayer, and others.
\end{abstract}

Keywords: Character Islami, Early Childhood, and Methods of Habituation.

\section{ABSTRAK}

Salah satu indikator keberhasilan keluarga muslim dalam mendidik anak adalah jike k karakter yang dimiliki oleh anak sesuai dengan nila-nilai Islam. Metode pendidikan yang hendak diterapkan dengan metode pembiasaan. Hasil dari penelitian ini adalah 1) Faktor-faktor yang berpengarub terhadap pembentukan karakter anak usia dini dapat dikategorikan menjadi 4 (empat) hal, yaitu: (a) lingkungan pendidikan yang pertama, yaitu keluarga yang diwakilkan oleh orang tua, (b) kehidupan keluarga yang dilihat dari berbagai aspek, baik status sosial ekonomi, filsafat bidup keluarga, maupun pola hidup keluarga, (c) pola asub keluarga, dan (d) kegiatan-kegiatan yang berbasis keagamaan yang biasa dilakukan orang tua dengan melibatkan anak usia dini didalamnya; dan 2) Pembiasaan yang dilakukan anak usia dini bersama orang tua dapat dikategorikan menjadi 2 (dua), yaitu: (a) pembiasaan ucapan, seperti mengucapkan salam, dan lain-lain; dan (b) pembiasaan yang ditampilkan dalam perbuatan, seperti: meninggalkean segala aktivitas ketika mendengar adzan, dan lain-lain.

Kata Kunci: Karakter Islami, Anak Usia Dini, dan Metode Pembiasaan. 


\section{INTRODUCTION}

Quality education is a future investment in facing global challenges. To achieve the expected output, then the education held should be directed and systemic design that starts from early childhood.

Early childhood is a small human who has a range of 0-6 years old is often referred to as a golden age, where children have many potentials that need to get stimulus always to be developed (Sofia Hartati, 2005).

Islam considers the importance of education for young children, especially in the context of character education. Imam Ghazali states that the character is closer to morality, that is, the spontaneity of man in attitude, or deeds that have been embedded in man so that when it appears, there is no need to think again (Abdul Majid and Dian Andayani, 2011).

Ibn Miskawayih reveals that moral education is an attempt towards the realization of an inner attitude that can encourage the birth of good deeds of a person (Muhammad Daud Ali, 1998) spontaneously. Thus, character education for early childhood is the process of giving guidance to early childhood to become a whole person of morality.

Every process of education required the method used to achieve the desired goals in education itself. In the process of Islamic education, the method has a significant position in achieving the goal (Hamdani Ihsan, 2003).

One method that is closely related to character formation in children, the method of habituation. The method of habituation is a practical way or effort in forming (coaching) and preparation of children (Abdullah Nasih Ulwan, 1992).

In shaping the character of the child, the effort not only teaches what is right and what is wrong with the child but more than that. Character education also embraces habituation about good, so children understand; Able to feel; And willing to do well (Kutsianto, 2014).

In addition to habituation efforts (child habituation) done, the need for the model from parents who can be a model for children. As the Prophet Muhammad SAW. Be a good uswah for his people (Surat alAhzab: 21)

Character education in Islamic education has a lot of value dimension that can be used as a guide. The values of character education in the person of Prophet Muhammad SAW. Who became the figure uswatun basanah summed up in the characters shidiq, Amanah, Fathonah, and Tabligh (M. Furqon Hidayatulloh, 2010). As the Prophet Muhammad SAW. Which is a good example for his people? So parents as adults should be good role models for their children. Because the family is the first and foremost environment in children's education.

The family is the first and foremost educational environment for children, family or parent education more emphasis on a moral aspect or personality formation than education to master science (Munardji, 2004).

Thus, the family or parents are the primary responsibility bearers of the sustainability of children's education at an early age. But not all parents have the insight, time and ability to shape the child's character by Islamic values caused by many factors. Therefore, as the responsible for the education of children, what steps and efforts should be done by parents in the family environment in shaping the character of Islam in early childhood.

Based on the background of the above problems, this study aims to determine: (1) Factors that affect the formation of character in early childhood in the family environment; And (2) Habits that parents need to do with young children in the home environment. 


\section{RESEARCH METHODS}

The method used in this research is an analytical, descriptive method. The descriptive-analytic method is an attempt to collect data that exist in the present (Winarno Surachmad, 2002). The technique used in this research is by literature study (book survey), that is by reading, understanding, analyzing, interpreting, and compiling from various book sources, so it can facilitate in solving problems related to the issues discussed with the intention that the results can be accounted for.

Writing this research can take knowledge as research material from some source, but in this case divided into two parts, namely primary data source, and secondary data source. Primary data in question are the books relating to the concept of family, the idea of Islamic character education, the concept of early childhood, and theories relating to the method of habituation. The secondary data is a variety of supporting books that have to do with the problems studied in this study.

\section{DISCUSSION}

Factors Affecting Early Childhood Character Formation in the Family Environment

The character of early childhood is formed from the closest environment that is informal with it, from birth until the age of 6 (six) years. The environment in question is a family of subjects in which are parents.

Parents are the oldest, free, first and foremost educational institutions experienced by children and schools that are natural, parents are responsible for maintaining, caring, protecting, and educating children to grow and develop well (Binti Maunah, 2009).

Factors affecting the personal development of children is the life of the family or parents along with various aspects, the development of children related to the development of psychology is influenced by socioeconomic status, family life philosophy, family life patterns such as discipline, concern for safety and order run the teachings of religion, A child is also determined by hereditary and environmental factors (Hasbullah, 2001).

The personality of parents, attitudes, and way of life are elements of education that will indirectly enter into the child's growing personal (Zakiah Daradjat, 1996).

Also, the character of early childhood is strongly influenced by the pattern of education, which is often referred to as parenting in the family. Broadly speaking, parenting patterns applied by parents to their children can be classified into (1) Authoritarian parenting, every parent in educating children requires that every child obediently submits to every parent's wishes. The child is not given the opportunity to inquire about the tasks, duties, and rights granted to him; (2) Democratic parenting pattern, the attitude of parents who want to listen to their children's opinions, then conducted consultation between parents' opinions and opinions of children and then taken a conclusion together, without any feel compelled; (3) Permissive parenting pattern, with parental attitudes in educating children, gives absolute freedom to children in acting without any direction so that for children whose behavior deviates will become children who are not accepted in society because he can not adjust to the environment (S. Nuryoto, 1993).

Early age is a good time to cultivate a character that conforms to Islamic values through activities that are commonly done by parents.

Childhood is the best time to absorb the basics of religious life, in this case of course happens in the family, for example by inviting children to participate in the mosque to worship, listen to sermons or religious lectures, such activities are very big Its influence on the character of the child, so life in the family should give the condition 
to the child to experience the atmosphere of religious life (Hasbullah, 2001).

Based on the description of the paragraph related to the formation of the character of early childhood above, it can be concluded that, the formation of early childhood character can be influenced by 4 (four) things, namely: (1) the first educational environment and the main informal, Families represented by parents; (2) family life seen from various aspects, whether related to socioeconomic status, family life philosophy, family life patterns such as discipline, concern for salvation and order run religious teachings, etcetera; (3) the pattern of care that is applied in the family environment, be it authoritarian, democratic, and permissive parenting patterns; And (4) religious-based activities commonly used by parents involving young children in it.

\section{Habits Parents Do With Involving Children}

One important factor in human behavior is a habit, because attitudes and behaviors that become morals (characters) very carefully to the habit, which is a habit are a repetitive act so easy to do. This habit factor plays a significant role in shaping and fostering morals (character) (Heri Gunawan, 2012).

So great is the role of habituation in the formation of the character of the child, so that Al-Ghazali reveals that, if the child is accustomed to practicing what is good, be educated in that direction, surely he will grow on the good is due to the positive he will survive in the world And the Hereafter. Both his parents and all his educators, teachers and guardians participated in the rewards. On the contrary, if the child has been accustomed to childhood to the ugliness and left unattended education and teaching, that is, as the child will be wretched and corrupted perish, whereas his main sin is certainly to be raised to the person (parent, educator) who is responsible for maintaining And nurture it (Zainuddin, et al., 1991).

Habituation is one of the most valuable educational tools. Therefore, from the beginning and as the base of education habituation is the only tool. From birth children should be trained with habits, both spoken, and in the form of good deeds. Children can obey and follow right rules, especially in the household or family (M. Ngalim Purwanto, 2009).

Habit is a behavior that is closely related to culture, in this case, is Islamic culture. Khambali (2016: 56) reveals that Islamic culture is the result of the linkage of Islam with culture. Islamic culture means a culture that breathes Islam.

Based on the explanation from the experts above regarding the habituation, the authors formulate the habits of parents by involving young children to form Islamic characters can be categorized into 2 (two), namely: (1) speech habituation; and (2) habituation displayed in deeds. The two habits in question will be described through the explanation below.

\section{Speech Preparation}

Saying a greeting is an expression of a prayer of salvation destined from a Muslim to another Muslim. If parents get used to saying hello when going to go and come in the family environment, then this habit is excellent. Because of this habit will be transmitted from one family member to another member, especially for children at an early age. In the Al-Munawwir dictionary, there is the word assalaamu 'alaikum (may be salvation for you) (Ahmad Warson AlMunawwir, 1997).

Some interpret the word greeting is peaceful, respectful statement (Team Compiler Dictionary of Language Center, 2002). Greetings mean safe or prosperous. In other terms, the salutation is a reference (tabiyyat) in the form of al-salam 's-prayer or complete as-salam' alaikum wa rahmat Allah wa barakatuh (May salvation and prosperity 
always be with you, as well as God's grace and blessings) To others. In addition to the greeting, Islam teaches the binding obligation to answer the greetings if it came from the oral of a Muslim and the way in responding to the greeting was varied (AnNawawi, 1994).

\section{Pray Before and After Eating}

Eating is an activity that can not be separated from life, then preferably before and after meals, early childhood has been accustomed to pray. With the hope that children learn to grate the blessings given by Allah SWT. The prayer before the meal, namely: "Bismillah" or may be equipped with "Bismillabirrabmaanirrabiim" (HR Muslim) (Abdullah Faqih, Vol.II). "As for after the meal, then the Prophet Saw. If it is finished from eating, at a time with sentences when lifting his stomach, he pronounces: "albamdulillabiladrii kafaanaa wa arwaanaa ghaira makfiyin wa laa makfuurin (All praise belongs only to God who has given us enough and eliminates thirst, not favors not considered), Or, "albamdulillabi rabbinaa ghaira makfiyin wa laa muwadda'in wa laa mustaghnan rabbanaa (All praise belongs only to our Lord Rabb, not a compliment not deemed and unnecessary by the God" (Narrated by al-Bukhari No. 5038).

\section{Pray Before and After Sleep}

Before going to sleep, parents should accompany early childhood to familiarize their children to pray before and after sleep. As for the prayer before going to bed, that is: "By calling Your name O Allah I am dead and alive" (Narrated by Bukhari 6312 and 6324 of Hudhayfa, Muslim 2711 of al-Bara 'ra). Moreover, if waking up from sleep, the child is accustomed to reciting the prayer, "Praise be to Allah who has brought us back to life after our previous death and to whom we have been restored" (Narrated by Bukhari and Muslim). By always getting used to praying before and after praying, the child will learn the importance of praying in every moment, especially when before and after rest.

\section{Praying When Entering and Exiting the Bathroom Room}

Routines of parents and young children enter the bathroom in a day and night is a habit that happens repeatedly. If every time in and out of the bathroom by applying sunnah-sunnah like praying, then parents and children have been practicing two Sunnah of the Prophet. When entering (putting the left foot and praying when entering) and the two Sunnah of the Prophet. When out (putting the right foot and prayer when it comes out).

The prayer when entering the bathroom is "O Allah; I am indeed taking refuge in you from the temptation of Shaytan of man and woman (Narrated by Bukhari and Muslim). While the prayer when out of the bathroom, namely: "I ask forgiveness to You (Hadith History All compilers sunan except AnNasaa'i).

\section{Reading the Qur'an After the Fajr Prayer and the Maghrib}

The habit that is expected to be maintained is to read al-Qur'an at the time after shubuh and maghrib, because it is such extraordinary benefits and wisdom.

Reading the Qur'an is the most important form of dhikr, in which there is a virtue in cleansing the heart, healing and soothing the soul "(Najati, 1993).

Also, the time is highly recommended by the Prophet Muhammad. To dhikr, is the time after maghrib and shubuh, because in it there is a blessing. The primacy of time shubub if used for learning and teaching, especially reading the Qur'an, then the virtue is given a real intelligence (Muhammad Djarat Sensa, 2004). 


\section{Say Thank You}

Saying thank you is easy, but if every time were spoken, it would be great benefits. In the expression of primary tit de, there are values of decency and respect for help. If parents are accustomed to thinking in the family environment, of early childhood will imitate that speech. Every time he gets help from his parents, sister or friend, he will say it with ease of thanks. Allah SW'T. Also asserted in the Qur'an that, whoever gives thanks to Allah SWT, then Allah SWT. Will add that enjoyment. However, if kufr, then the punishment of Allah SWT. Will be paid (Surah Ibrahim: 7).

\section{Say Sorry}

The apology (punten; sundanese language) is part of a tradition consistent with Islamic values. However, for some people, saying sorry is judged as an expression if it is proven guilty. In the family, if this apology (punten; sundanese language) becomes a tradition that every day is spoken, then the family climate will always be harmonious and romantic. Moreover, if there is a wrong family member or misunderstanding, you should immediately apologize and forgive each other, because of Allah SWT. Like it (Quran Ali Imran: 134). So actually young children will learn a lot from the habit of saying the word "sorry" in the family environment. Therefore, it is necessary to say sorry if guilty and ask for help habitually.

\section{No Fighting Taking the Road of Deliberation}

The bickering behavior usually brings out impolite, rude and unkind words to say. If someone in his or her daily struggles with various intensity, or even no day without a fight, then certainly he will have a rough and problematic character. Moreover, if the argument that occurs in front of early childhood is done every day and has become a habit, then the child will experience various problems, ranging from communication problems, mental and psychological problems, or also character problems that need special and intensive treatment. In Islam, if there is a difficult issue to solve, then one way is to hold a deliberation to find its middle way (Surah Ali Imran: 159).

\section{Telling By Doing It}

Telling is a phrase addressed to someone for the person to do something. The habit of telling it will be a problem if one tells them not to do the instructions. So that the Qur'an of Allah SWT. The abusive man who likes to tell but he did not do it (Surah As-Shaaf: 2-3). Indeed, early childhood quickly learns from what he saw and experienced.

\section{No Complaining and Despair of Circumstances}

The expression of complaining, perhaps often spoken by some people who are not grateful for what God Almighty. However, if the expression of complaining is spoken from the parents in front of the child repeatedly, then indirectly children learn from the attitude of their parents about the meaning of gratitude for what Allah Almighty. Give it away. Whereas the Qur'an teaches that humanity does not despair of Allah's grace (Surah Yusuf: 87) and is always grateful for what Allah has bestowed (Surat Luqman: 12). Therefore, parents should more often express grateful sentences for the blessings that Allah Almighty. Give, so the child will learn to accept whatever conditions Allah Almighty. Give it away.

\section{Not Defaming Others' Names}

Parents are a mirror for the child, what the parents say, then the child will imitate. As in the case of gossiping, cursing, slandering, beating, calling with bad names and so forth (Al-Mukminun: 5). The child will learn it all if his parents used to say it. 
Therefore parents should set a good example of this. Islam also humiliates those who commit these sins, also threatens them with a painful promise on the Day of Judgment, and puts them into the class of the wicked (Qs Al-Qalam: 10-12, Qs AlHumazah: 1).

\section{Speak with Courteous and Soft Gentle}

In daily intercourse, speaking politely and gently is the noblest way of talking that should be part of the interaction in the family environment. This has an impact on how to communicate with children in the future. In Islam, the noble utterance is an utterance related to the right and the way God likes (Surat al-Isra ': 23).

\section{Habituation of Works \\ Prayer Jamaat in the mosque}

Prayer congregation is a worship that is held together filled with social values. So if the prayer congregation is familiarized in the family environment, then the child will get a good experience of togetherness.

The congregational prayer has an intrinsic meaning to tie vertical relationship with God, and instrumental meaning serves to educate a noble person and then be able to socialize into society "(Moh Sholeh and Imam Musbikin, 2005).

From the motor aspect, the child of early childhood has been able to control his movements so as to perform movements, for example by prayer; the child has been able to do so. Therefore, parents should familiarize their children to pray together in the mosque. The hope is that the child will have a sense of responsibility to perform the prayer and establish a real religious soul in the child in the future.

Visiting Families, Relatives, and Sick Neighbors

Habits of parents by inviting children to visit the sick, whether visiting family, relatives and neighbors is a very habit of educating children to care about each other. Because in Islam, visiting a sick person has a virtue, as explained by the Prophet (s), "Whoever visits the sick, he is always on the date palm pickup in heaven until he comes home" (Muslim).

\section{Respect to the Older and the Mighty to the Younger}

Early children learn much from what they see. The child who is accustomed to being invited to visit his grandparents, in fact, he is being taught about respecting both parents. The attitude of respect is not only aimed at parents and teachers, but it is aimed at older people, like their siblings. The etiquette in everyday relationships not only honor the parents only. However, to a younger age should be appreciated and given love.

\section{Respect Neighbors}

Neighbors are one of the environments adjacent to someone who has a family (married). Parents behaviors commonly shown in the attitude to the neighbors, of course, will be followed by his children. Therefore, it is necessary to teach children and get used to behave to the neighbors with respect and help each other, and do not become a parasite and tuneful Harmonists of neighbor life.

\section{Visiting Families, Relatives and Affected Neighbors}

The trials of life experienced by a person both physical and non-physical will befall all people, whether in the form of hunger, thirst, pain, fear, loss of loved ones, loss of property and so forth. As parents should prepare their children to learn to accept the circumstances or the test is given by God Almighty. To His servant. By getting used to visiting family, relatives and neighbors who are being tested by Allah 
SWT, then actually the child is learning life so that the child becomes a servant of Allah SWT. Who always be patient and ready to be a devout Muslim to Him.

\section{Maintain Personal and Environmental Hygiene}

Mother is the first person a child encounters in her life. Therefore, any behavior, how to educate children, and habits can be an example for his son. Likewise in instilling knowledge and habituation about the importance of maintaining personal hygiene and environment, such as ablution before bed, brush your teeth before bed and after, wash hands before eating, bathe in time, littering, and other behaviors that teach and familiarize Children to maintain personal hygiene and environment.

\section{Leave All Activities When Hearing the Adhan}

Adhan is Allah's call. To perform the prayers. When the call to prayer, the parents should abandon all the activities that are being done, and immediately take the ablution water to carry out the prayers. Parents who are obedient to Allah SWT. Certainly, expect their children also to familiarize his behavior to his children, children will follow the pattern of life that has been applied in the everyday lives of children. So with the learning and habituation done since early childhood, then the child when stepping on the age of adolescence or even adults, children are accustomed that the habit will be a strong child character.

Dress Courteously With Aurat Closing, and Not Excessively in Dressing

Children who are taught and accustomed to wearing a decent dress and covering aurat, would be different from children who are accustomed to wearing clothes that are open and visible aurat.
Children who are accustomed to wearing clothes politely and cover aurat, of course when he was teenager or adult, he will quickly understand and practice the teachings of Islam about closing aurat. In fact, he will find his postulates that make up the habits he did since he was little. Also, by covering the nakedness from childhood by dressing not excessively, then actually he is being taught the importance of maintaining the trust of Allah SWT, because aurat is a trust that God entrusted to man, with no exaggeration in decorating it.

\section{CONCLUSION}

From the above discussion, it can be concluded as follows:

Factors influencing the formation of early childhood character can be categorized into 4 (four) things, namely: (a) first and foremost education environment that is informal, that is family environment represented by a parent; (b) family life seen from various aspects, be it related to socioeconomic status, family life philosophy, family life patterns such as discipline, concern for salvation and order run religious teachings, etcetera; (c) the pattern of care adopted in the home environment, be it authoritarian, democratic, and permissive parenting habits; and (d) religious-based activities that parents usually engage in early childhood involvement.

To establish Islamic character at the beginning of childhood, habituation done by an early childhood with parents can be categorized into 2 (two), namely: (a) speech habituation, like say a greeting, pray in every activity, read al- Qur'an, say thank you, make an apology, do not quarrel, told accompanied by doing it, and others; And (b) habits displayed in the act, such as: leaving all activities when hearing the call to prayer, praying in congregations in the mosque, visiting sick relatives, maintaining personal hygiene, respect for the elderly, and others. 


\section{REFERENCES}

Al-Munawwir, Ahmad Warson. (1997). Kamus Al-Munawnir Arab-Indonesia Terlengkap, Yogyakarta: Pustaka Progressif.

An-Nawawi. (1994). Riyadhus Shalibin. Beirut: Daar al-Fikr.

Daradjat, Zakiah. (1996). Ilmu Pendidikan Islam. Jakarta: Bumi Aksara.

Daud Ali, Muhammad. (1998). Pendidikan Agama Islam. Jakarta: PT RajaGrafindo Persada.

Faqih, Abdullah. Volume II/4069. Fatawa al-Syabakah al-Islamiyah alMuaddalah.

Gunawan, Heri. (2012). Pendidikan Karakter Konsep dan Impementasi. Bandung: Alfabeta.

Hartati, Sofia. (2005). Perkembangan Belajar pada AUD. Jakarta: Depdiknas.

Hasbullah. (2001). Dasar-dasar Ilmu Pendidikan. Jakarta: PT Raja Grafindo Persada.

Hidayatullah, M. Furqon. (2010). Pendidikan Karakter Membangun Peradaban Bangsa, Yuma Presindo, Surakarta.

Ihsan, Hamdani. (2003). Filsafat Pendidikan Islam, Bandung: Pustaka Setia.

Khambali. (2016). "Konseptual Model Internalisasi Budaya Islami Pada Anak di Lingkungan Keluarga". Jurnal Taklim: Jurnal Pendidikan Agama Islam Vol. 14. No. 1 Maret 2016, pp. 56.

Kutsianto. (2014). Pdf: Metode Pembiasaan Sebagai Media Pembentukan Karakter Anak. Yogyakarta: UIN Sunan Kalijaga. (http://digilib.uinsuka.ac.id/13551/2/BAB $\% 20 I, \% 2$ 0IV,\%20DAFTAR $\% 20$ PUSTAKA. pdf). Diakses pada 27-02-2016.

Majid, Abdul \& Dian Andayani. (2011). Pendidikan Karakter Perspektif Islam. Bandung: PT Remaja Rosdakarya.

Maunah, Binti. (2009). Ilmu Pendidikan. Yogyakarta: Teras.
Moh Sholeh, Imam Musbikin. (2005). Agama Sebagai Terapi. Yogyakarta: Pustaka Pelajar.

Munardji. (2004). Ilmu Pendidikan Islam. Jakarta: PT Bina Ilmu.

Najati, M. Utsman. (1993). Belajar EQ dan SQ dari Sunnab Nabi. Jakarta: Hikmah.

Nuryoto, S. (1993). "Kemandirian Remaja Ditinjau dari Tahap Perkembangan Jenis Kelamin dan Peran Jenis". Journal Psikologi Tabun XX No. 2. Yogyakarta: Fakultas Psikologi UGM.

Purwanto, M. Ngalim. (2009). Ilmu Pendidikan Teoretis Dan Praktis. Bandung: PT. Remaja Rosdakarya.

Sensa, Muhamad Djarat. (2004). Quranic Quontient Kecerdasan-kecerdasan Bentukan Al-Qur'an. Jakarta: Hikmah.

Surachmad, Winarno. (2002). Pengantar Penelitian Ilmiah. Bandung: Tarsito.

Ulwan, Abdullah Nasih. (1992). Tarbiyatul Aulad fil Islam, Terj: Pendidikan Anak Menurut Islam. Bandung: Rosda Karya.

Zainuddin, et,al. (1991). Seluk-Beluk Pendidikan dari Al-Ghazali. Jakarta: Bumi Aksara. 